\title{
Digestive adaptations of rats given white bread and cooked haricot beans (Phaseolus vulgaris): large-bowel fermentation and digestion of complex carbohydrates
}

\author{
BY FIONA B. KEY AND J. C. MATHERS* \\ Department of Biological and Nutritional Sciences, University of Newcastle upon Tyne, \\ Newcastle upon Tyne NEI 7RU
}

(Received 8 July 1994-Accepted 24 August 1994)

Two experiments were carried out to examine the short (1-3 d) and medium (14 d) term adaptations of rat large-bowel (LB) fermentation to alterations in substrate supply brought about by including cooked haricot beans (Phaseolus vulgaris) in diets based on white bread. Changes in organic matter (OM) flow from the ileum occurred within $1 \mathrm{~d}$ and were stable for $14 \mathrm{~d}$ but the pattern of caecal short-chain fatty acids took much longer to stabilize with considerable increases in butyrate between 1 and $3 \mathrm{~d}$ and up to $14 \mathrm{~d}$. This suggests that the metabolic activity of the LB microflora may take a considerable time to stabilize after an abrupt change in substrate supply. Despite an almost fourfold change in OM supply to the $L B$, the proportion of this $O M$ apparently fermented in that organ (0-46) remained fairly constant. None of the apparent resistant starch measured in the diets could be detected in faeces. Dietary nonstarch polysaccharides (NSP) were extensively fermented with similar values (0.82) for both bread and bean NSP and there was little indication of any interaction between the two diet components on NSP fermentation. An attempt was made to fractionate ileal and faecal $O M$ to provide a basis for a quantitative model of LB stoichiometry.

White bread: Haricot beans: Large-bowel fermentation: Complex carbohydrates

Fermentation of carbohydrates and other organic materials is now known to be a major function of the large bowel (LB) in man and other omnivorous animals. The substrates for fermentation supplied via digesta entering the LB from the terminal ileum can be readily modified by diet. In man the major fermentation substrates appear to be starches resistant to pancreatic $\alpha$-amylase (EC 3.2.1.1) and non-starch polysaccharides (NSP; Cummings \& Englyst, 1987), so that foods rich in these carbohydrate fractions are likely to have significant effects on LB fermentation and subsequent metabolic events in the gut mucosa, liver and other tissues. Cooked haricot beans (Phaseolus vulgaris) were used in the present study since, in common with other leguminous seeds, they contain a relatively high proportion of resistant starch (RS; Englyst \& Kingman, 1990), are a concentrated source of NSP (Englyst \& Cummings, 1984) and are a frequent component of Western diets. Studies of LB fermentation in man are severely hampered by the relative inaccessibility of the target organ and experimental animals, usually rats, have been used as a model. Despite major anatomical differences, there is some evidence that the extent of fermentation may be fairly similar (Nyman et al. 1986; Mathers, 1991) for these two species.

Short-chain (or volatile) fatty acids (SCFA) are the main end-products of carbohydrate fermentation in the LB and there is growing evidence that each of these acids may have specific effects on tissue metabolism (Roediger, 1982; Sakata, 1987; Venter \& Vorster, 1989). Consequently it is important to know not only the total amount of substrate

\footnotetext{
* For reprints.
} 
fermented but the pattern of SCFA produced. Several studies in rats (e.g. Cheng et al. 1987; Tulung et al. 1987; Mallet et al. 1988; Walter et al. 1988; Goodlad \& Mathers, 1990; Mathers et al. 1990) and more limited findings in man (Scheppach et al. 1988) have shown that LB fermentation pattern is readily modified by additional supplies of RS and NSP but as yet there is no means of predicting fermentation pattern. In addition it is not known how rapidly LB fermentation in vivo responds to alterations in diet. When wheat bran or gum arabic was added to a semi-purified (Walter et al. 1986) or an elemental diet (Walter et al. 1988), rat caecal fermentation pattern continued to change over the 12 weeks of the studies (measurements made at 4,8 and 12 weeks). Changes over a shorter time-scale may be more relevant to man where the composition of the diet often varies from day to day.

In the present study, two experiments were carried out. In the first, rats were fed on a basal, low-NSP diet containing $500 \mathrm{~g}$ freeze-dried white bread $/ \mathrm{kg}$ and then half of the animals were changed to a diet supplemented with $450 \mathrm{~g}$ freeze-dried, cooked haricot beans $/ \mathrm{kg}$. Measurements of caecal fermentation pattern and other variables were made at 1,2 and $3 \mathrm{~d}$ after diet change. In the second experiment, diets containing graded concentrations of beans $(0-450 \mathrm{~g} / \mathrm{kg}$ diet $)$ were fed for $14 \mathrm{~d}$ to determine longer term effects of ingestion of large amounts of complex carbohydrates on caecal fermentation and to provide quantitative estimates of the extent of fermentation of these polymers.

\section{MATERIALS AND METHODS}

Animals and housing

Fifty male Wistar rats were obtained from the Comparative Biology Centre, University of Newcastle upon Tyne and housed in individual plastic metabolism cages in a controlledenvironment room in this Centre throughout the study.

\section{Experimental protocol}

Two studies were carried out concurrently using the same diets and rats from the same batch. The first study (adaptation experiment) examined changes when rats initially fed on a low-NSP, white-bread-based diet (WH1) were transferred to one containing $450 \mathrm{~g}$ cooked haricot beans/kg (WH4). The second study (balance experiment) was of a conventional design and compared complex carbohydrate digestion and LB fermentation in animals given each of the four experimental diets. Temporal organization of the animal experiments is illustrated diagrammatically in Fig. 1. Initially all fifty rats were offered diet WH1. After $10 \mathrm{~d}$ the rats were divided at random into two groups, thirty for the adaptation experiment and the remaining twenty for the balance experiment. For the adaptation experiment, fifteen rats continued on diet WH1 whilst the other fifteen were changed immediately to diet WH4. Five rats from each diet group were killed on days 1, 2 and 3 after introduction to the new diet. For the balance experiment the twenty rats were split into four groups, each of five rats, with one group continuing on diet WH1 and the others allocated to each of the remaining three experimental diets containing graded concentrations of cooked haricot beans. After $7 \mathrm{~d}$ adaptation there followed a $7 \mathrm{~d}$ balance period with measurement of food intake and complete collection of faeces and urine.

\section{Diets and feeding}

Four experimental diets were prepared (Table 1), each containing $500 \mathrm{~g}$ freeze-dried white bread (Robertsons Bakers, Carlisle, Cumbria) $/ \mathrm{kg}$ and $0-450 \mathrm{~g}$ cooked and freeze-dried haricot beans $/ \mathrm{kg}$ included in place of sucrose and casein to maintain similar crude-protein concentrations based on values in Paul \& Southgate (1978). All diets were supplemented with vitamins and minerals and maize oil to provide essential fatty acids and contained 


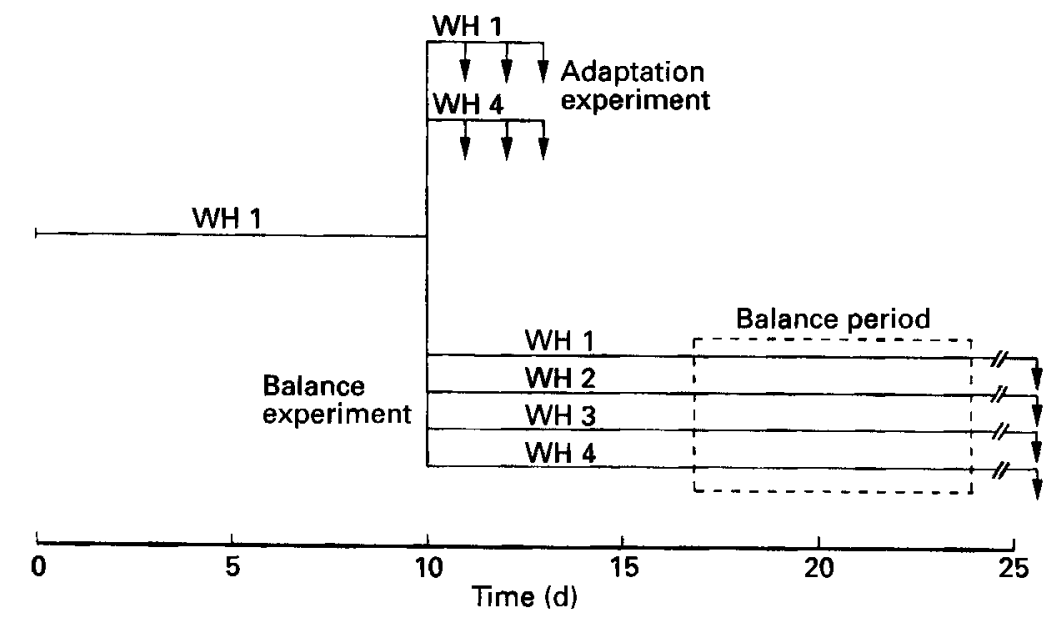

Fig. 1. Time line for the present study showing how the fifty rats initially fed on diet WH1 for $10 \mathrm{~d}$ were then allocated to the adaptation experiment (thirty rats) and the balance experiment (twenty rats). The arrows represent times when five rats/diet were slaughtered. The hatched box indicates the balance period when food intake was measured and complete collections of urine and faeces were made. Diets WH1, WH2, WH3 and WH4 contained 0, 150, 300 and $450 \mathrm{~g}$ freeze-dried, cooked haricot beans (Phaseolus vulgaris) $/ \mathrm{kg}$ diet (for further details, see Table 1).

$2 \mathrm{~g} \mathrm{Cr}_{2} \mathrm{O}_{3} / \mathrm{kg}$ as an indigestible flow marker. Animals were offered $15 \mathrm{~g}$ air-dry food at 10.00 hours daily with uneaten food removed the following morning. Water was available ad lib.

\section{Measurements}

Each rat was injected intraperitoneally with the metaphase arrest agent vincristine sulphate at $1 \mathrm{mg} / \mathrm{kg}$ body weight $(0.5 \mathrm{mg}$ vincristine sulphate $/ \mathrm{ml}$ sterile saline $(9 \mathrm{~g} \mathrm{NaCl} / 1))$ for measurements of crypt-cell proliferation which will be reported separately, and $2 \mathrm{~h}$ later was anaesthetized by intraperitoneal injection of Hypnorm/Midazolam $(1 \mathrm{ml} / 300 \mathrm{~g}$ body weight, prepared by the Comparative Biology Centre, University of Newcastle upon Tyne).

Blood, digesta and tissue samples were collected as described by Goodlad \& Mathers (1990). In addition, the masses of stomach and stomach tissue and of colon and colonic tissue were measured. Samples of gut tissue were also removed for histological examination, the results of which will be reported separately.

\section{Analytical methods}

The method of Englyst \& Cummings (1984) was used for measuring NSP and its constituents and apparent RS was determined by omitting the dimethyl sulphoxide addition step. This form of RS is probably mainly retrograded amylose $\left(\mathrm{RS}_{3}\right.$; Englyst et al. 1992). $\mathrm{N}$ in diets, faeces and urine was determined by a Kjeldahl procedure, $\mathrm{Cr}_{2} \mathrm{O}_{3}$ and SCFA in caecal digesta as described by Mathers et al. (1990), organic matter (OM) by heating at $500^{\circ}$ for $16 \mathrm{~h}$, and 3-hydroxybutyrate (3OHB) in deproteinized blood enzymically (Lloyd et al. 1978). Concentrations of SCFA in blood from the portal vein and heart were determined as described by Goodlad \& Mathers (1990).

\section{Statistical methods}

Adaptation experiment. Two-factor ANOVA was used to examine the effects of diet (WH1 v. WH4), of time of exposure to the diet (d) and of the interaction between diet and time. In each case, the effects of time and the corresponding interaction term were split into 
Table 1. Formulation $(\mathrm{g} / \mathrm{kg})$ and analysed composition $(\mathrm{g} / \mathrm{kg} \mathrm{DM})$ of diets

\begin{tabular}{|c|c|c|c|c|}
\hline Diet... & WH1 & WH2 & WH3 & WH4 \\
\hline White bread* & 500 & 500 & 500 & 500 \\
\hline Haricot beans $\dagger$ & 0 & 150 & 300 & 450 \\
\hline Sucrose & 347 & 232 & 117 & 0 \\
\hline Casein + methionine $\ddagger$ & 99 & 66 & 33 & $2 \S$ \\
\hline Vitamin + mineral mix $\|$ & 24 & 24 & 24 & 24 \\
\hline Maize oil & 30 & 28 & 26 & 24 \\
\hline \multicolumn{5}{|l|}{ Analysed composition (g/kg DM) } \\
\hline DM (g/kg air-dry diet) & 972 & 966 & 962 & 952 \\
\hline Nitrogen & $24 \cdot 2$ & $24 \cdot 7$ & $25 \cdot 9$ & $26 \cdot 7$ \\
\hline Total NSP & $15 \cdot 4$ & $44 \cdot 2$ & $78 \cdot 2$ & $111 \cdot 8$ \\
\hline $\mathrm{NCP}$ & $14 \cdot 0$ & $40 \cdot 0$ & $70 \cdot 3$ & 99.6 \\
\hline Cellulose & 1.4 & $4 \cdot 2$ & $8 \cdot 1$ & $12 \cdot 2$ \\
\hline Rhamnose & 0 & $0 \cdot 1$ & $0 \cdot 3$ & 0.5 \\
\hline Arabinose & 3.4 & $9 \cdot 8$ & $16 \cdot 8$ & $23 \cdot 3$ \\
\hline Xylose & $4 \cdot 6$ & 6.7 & $9 \cdot 0$ & 11.0 \\
\hline Mannose & 0.6 & 0.8 & $1 \cdot 1$ & 1.6 \\
\hline Galactose & 0.6 & $2 \cdot 2$ & $3 \cdot 6$ & $5 \cdot 2$ \\
\hline Glucose & $5 \cdot 4$ & $12 \cdot 4$ & $23 \cdot 2$ & $34 \cdot 0$ \\
\hline Uronic acids & 0.9 & $12 \cdot 5$ & $25 \cdot 2$ & 37.8 \\
\hline Resistant starch & $5 \cdot 2$ & $10 \cdot 7$ & $13 \cdot 6$ & $17 \cdot 6$ \\
\hline
\end{tabular}

NSP, non-starch polysaccharides; NCP, non-cellulosic polysaccharides.

* Supplied by Robertsons Bakers, Carlisle, Cumbria. Freeze-dried and ground to pass a $1 \mathrm{~mm}$ screen.

$\dagger$ Autoclaved at $10 \mathrm{psi}(69 \mathrm{kPa})$ for $10 \mathrm{~min}$. Freeze-dried and ground to pass a $1 \mathrm{~mm}$ screen.

¥ Casein-L-methionine (100:5, w/w).

\& L-methionine only.

\| Contained (g/kg premix): $\mathrm{CaH}_{2} \mathrm{PO}_{4} 593, \mathrm{MgSO}_{4} .7 \mathrm{H}_{2} \mathrm{O} 84, \mathrm{KCl} 236, \mathrm{MnSO}_{4} .4 \mathrm{H}_{2} \mathrm{O} 5 \cdot 7, \mathrm{FeSO}_{4} .7 \mathrm{H}_{2} \mathrm{O} 4 \cdot 4$, $\mathrm{ZnSO}_{4} .7 \mathrm{H}_{2} \mathrm{O} 7.8$, choline chloride 56 and $\left(\mathrm{mg} / \mathrm{kg}\right.$ premix): $\mathrm{CuCl}_{2} .2 \mathrm{H}_{2} \mathrm{O} 450, \mathrm{KIO}_{3} 10$, Rovimix AD $\mathrm{ADoche}_{3}$ Products Ltd, Welwyn Garden City, Herts) 415, Rovimix E50 (Roche) 2500, menadione 200, pteroylglutamic acid 40, calcium pantothenate 300, riboflavin 150, thiamin hydrochloride 150 , niacin 415 , cyanocobalamin 2.

9. Probably mainly retrograded amylose $\left(\mathrm{RS}_{3}\right)$ : other forms of resistant starch are not measured by this analytical procedure.

(1) linear and (2) deviations from linear effect of time and each tested against the betweenanimals within-treatments variation with 24 degrees of freedom.

Balance experiment. Data were analysed by one-factor ANOVA with orthogonal polynomials used to describe the response to varying dietary concentration of haricot beans. The between-animals within-diets variation with 16 degrees of freedom was used as the error term. Separate estimates of apparent digestibility of polysaccharides in white bread and in beans were obtained by a multiple linear regression (MLR) procedure described by Key \& Mathers (1993 a). In the present study, two MLR models were used:

MLR model 1: $\quad Y=\alpha_{1} X_{1}+\alpha_{2} X_{2}+\alpha_{3} X_{1} X_{3}$,

where $Y$ is NSP output in faeces, $X_{1}$ and $X_{2}$ are intakes of NSP from white bread and beans respectively, $X_{3}$ has the value of 0 or 1 when beans were absent from or present in the diet respectively, $\alpha_{1}$ and $\alpha_{2}$ are the coefficients of indigestibility of NSP in white bread and beans respectively, and $\alpha_{3}$ is the additional effect of presence of beans on white bread NSP indigestibility. Where $\alpha_{3}$ is not significant, a simpler model is appropriate:

MLR model 2: $\quad Y=\beta_{1} X_{1}+\beta_{2} X_{2}$, 
where $\beta_{1}$ and $\beta_{2}$ are the coefficients of indigestibility for bread and beans respectively. Apparent digestibilities were calculated by subtracting the appropriate coefficients of indigestibility from unity.

\section{RESULTS}

\section{Adaptation experiment}

One day after changing abruptly from the no-beans diet (WH1) to that containing $450 \mathrm{~g}$ haricot beans $/ \mathrm{kg}$ (WH4), the daily flows of DM and OM from the terminal ileum into the LB increased by $2.5 \mathrm{~g}$ (from a basal diet mean of $2.2 \mathrm{~g}$ ) and $1.9 \mathrm{~g}$ (from a basal diet mean of $0.7 \mathrm{~g}$ ) respectively (Table 2 ). Further changes over time were not statistically significant. Digestibility of DM, measured by the marker ratio method, decreased from 0.85 to 0.68 (terminal ileum) and 0.96 to 0.86 (caecum) following the diet change.

Caecal $\mathrm{pH}$ fell significantly within $1 \mathrm{~d}$ of diet change with no further effect over the next $2 \mathrm{~d}$ (Table 3). This was associated with an increase of approximately $27 \mathrm{mmol} \mathrm{SCFA} / \mathrm{kg}$ caecal contents which was maintained. The diet change provoked no significant effect on the molar proportion of acetate in caecal SCFA, but butyrate increased linearly over the $3 \mathrm{~d}$ on diet WH4 at the expense of propionate and the minor SCFA (isobutyrate, isovalerate and valerate).

With diet WH1, acetate was the dominant SCFA detected in portal blood with concentrations approximately 10 and 30 times greater than for propionate and butyrate respectively (Table 4). When changed to diet $\mathrm{WH} 4$, rats showed rapid and sustained increases in the concentrations of all three SCFA with no detectable changes over the $3 \mathrm{~d}$ sampling period. Acetate, propionate and butyrate were, on average, 297, 99 and $96 \mu \mathrm{mol} / 1$ higher in portal blood from animals eating diet WH4 compared with those eating WH1. As a proportion of the concentration with diet WH1, the rise in butyrate concentration with diet WH4 was most marked at almost fivefold. Acetate and propionate were the only SCFA detected reliably in blood from the heart and whilst both tended to increase with the bean-containing diet, the increases were not statistically significant. There were significant increases of $2 \cdot 3$ - and $2 \cdot 8$-fold in the concentrations of $3 \mathrm{OHB}$ in portal and heart blood respectively in WH4 compared with WH1 rats and there was a significant $(P<0.05)$ linear fall over the 3 sampling days.

\section{Balance experiment}

The bean-containing diets had slightly lower DM concentrations (Table 1) so that there was a small but statistically significant fall in DM intake with increasing proportion of beans in the diet (Table 5). Weight gain changed curvilinearly with diet showing a maximum for diet $\mathrm{WH} 2$ and a minimum for diet WH4. Because of the higher $\mathrm{N}$ concentration in the bean-containing diets (Table 1), $\mathrm{N}$ intake increased from diets WH1 to WH4 but the maximum difference was only $0.18 \mathrm{~g} \mathrm{~N} / \mathrm{d}$ (Table 5 ). Bean consumption resulted in much larger changes in faecal $\mathrm{N}$ output so that there was 4.7 times more faecal $\mathrm{N}$ with diet WH4 than with the no-bean diet (WH1). Approximately half of the ingested $\mathrm{N}$ appeared in urine with lower outputs for the middle two diets (WH2 and WH3) than for the two extremes (WH1 and WH4). When data for all diets were combined there was strong linear relationship between weight gain $(X ; \mathrm{g} / 7 \mathrm{~d})$ and $\mathrm{N}$ balance $(Y ; \mathrm{mg} / 7 \mathrm{~d})$ which could be described by the equation:

$$
Y=18.9(\text { SD } 3.34) X+113(\text { SD } 127) ; r^{2} 0.639(P<0.001) \text {. }
$$

The intercept was not significantly different from zero. The reduced growth rate for rats offered diet WH4 was probably due to a combination of lower DM intake, reduced diet digestibility and a lower yield of metabolizable energy from the larger amount of dietary 
Table 2. Adaptation experiment. Flows of DM and organic matter $(O M)$ from the terminal ileum and apparent digestibility of $D M$ measured at the terminal ileum and caecum of rats previously adapted to a white-bread-based diet ( $\mathrm{WH} 1 ; 0 \mathrm{~g}$ beans $/ \mathrm{kg}$ ) for $10 \mathrm{~d}$ and either continuing on this diet or changing to diet $\mathrm{WH} 4$ (450 g haricot beans (Phaseolus vulgaris) $/ \mathrm{kg}$ ) for a further $3 d \dagger$

(Mean values for five rats per treatment)

\begin{tabular}{|c|c|c|c|c|c|c|c|c|c|c|c|c|}
\hline \multirow{3}{*}{$\begin{array}{l}\text { Diet ... } \\
\text { Beans in diet }(\mathrm{g} / \mathrm{kg}) \text {. } \\
\text { Sampling day ... }\end{array}$} & \multirow{2}{*}{\multicolumn{3}{|c|}{$\begin{array}{c}\text { WH1 } \\
0\end{array}$}} & \multirow{2}{*}{\multicolumn{3}{|c|}{$\begin{array}{c}\text { WH4 } \\
450\end{array}$}} & \multirow[b]{3}{*}{ SEM } & \multicolumn{5}{|c|}{ Statistical significance of treatments } \\
\hline & & & & & & & & \multirow[b]{2}{*}{ Diet } & \multirow{2}{*}{$\begin{array}{l}\text { Time } \\
\text { (Lin) }\end{array}$} & \multirow{2}{*}{$\begin{array}{l}\text { Time } \\
\text { (Dev) }\end{array}$} & \multirow{2}{*}{$\begin{array}{l}\text { Diet } x \\
\text { time } \\
\text { (Lin) }\end{array}$} & \multirow{2}{*}{$\begin{array}{l}\text { Diet } \times \\
\text { time } \\
\text { (Dev) }\end{array}$} \\
\hline & 1 & 2 & 3 & 1 & 2 & 3 & & & & & & \\
\hline \multicolumn{13}{|l|}{ Ileal flow $(\mathrm{g} / \mathrm{d})$} \\
\hline DM & $3 \cdot 11$ & 1.84 & $1 \cdot 63$ & $4 \cdot 70$ & 4.52 & $4 \cdot 40$ & 0.641 & $* * *$ & NS & NS & NS & NS \\
\hline OM & 0.83 & 0.62 & 0.62 & $2 \cdot 61$ & $2 \cdot 55$ & $2 \cdot 54$ & $0 \cdot 145$ & $* *$ & NS & NS & NS & NS \\
\hline \multicolumn{13}{|l|}{ DM digestibility } \\
\hline Ileum & 0.79 & 0.87 & 0.89 & 0.67 & 0.68 & 0.69 & 0.025 & $* * *$ & $*$ & NS & NS & NS \\
\hline Caecum & 0.96 & 0.96 & 0.96 & 0.87 & 0.85 & 0.86 & 0.007 & $* * *$ & NS & $*$ & NS & NS \\
\hline
\end{tabular}

Lin, linear; Dev, deviations from linear effect.

* $P<0.05 ; * * P<0.01 ; * * * P<0.001$.

$\dagger$ See Table 1 for diet details and Fig. 1 for experimental design.

$\ddagger$ See pp. 395-397 for further details of statistical methodology.

$\S$ Estimated by the marker ratio method.

Table 3. Adaptation experiment. Caecal pH and short-chain fatty acids (SCFA) in rats previously adapted to a white-bread-based diet ( $W H 1 ; 0 \mathrm{~g}$ beans/ $\mathrm{kg}$ ) for $10 \mathrm{~d}$ and either continuing on this diet or changing to diet WH4 (450 g haricot beans (Phaseolus vulgaris)/ $\mathrm{kg}$ ) for a further $3 d_{\dagger}$

(Mean values for five rats per treatment)

\begin{tabular}{|c|c|c|c|c|c|c|c|c|c|c|c|c|}
\hline \multirow{3}{*}{$\begin{array}{l}\text { Diet ... } \\
\text { Beans in diet }(\mathrm{g} / \mathrm{kg}) \ldots \\
\text { Sampling day ... }\end{array}$} & \multirow{2}{*}{\multicolumn{3}{|c|}{$\begin{array}{c}\text { WH1 } \\
0\end{array}$}} & \multirow{2}{*}{\multicolumn{3}{|c|}{$\begin{array}{c}\text { WH4 } \\
450\end{array}$}} & \multirow[b]{3}{*}{ SEM } & \multicolumn{5}{|c|}{ Statistical significance of treatments $\ddagger$} \\
\hline & & & & & & & & \multirow[b]{2}{*}{ Diet } & \multirow{2}{*}{$\begin{array}{l}\text { Time } \\
\text { (Lin) }\end{array}$} & \multirow{2}{*}{$\begin{array}{l}\text { Time } \\
\text { (Dev) }\end{array}$} & \multirow{2}{*}{$\begin{array}{c}\text { Diet } x \\
\text { time } \\
\text { (Lin) }\end{array}$} & \multirow{2}{*}{$\begin{array}{c}\text { Diet } x \\
\text { time } \\
\text { (Dev) }\end{array}$} \\
\hline & 1 & 2 & 3 & 1 & 2 & 3 & & & & & & \\
\hline $\begin{array}{l}\text { Caecal pH } \\
\text { Total SCFA } \\
\text { (mmol } / \mathrm{kg} \mathrm{caecal} \\
\text { contents) }\end{array}$ & $106^{6 \cdot 3}$ & $\begin{array}{l}6.4 \\
94\end{array}$ & $100^{6.4}$ & $\begin{array}{c}5.9 \\
128\end{array}$ & $131^{62}$ & $\begin{array}{r}6.0 \\
123\end{array}$ & $\begin{array}{c}0 \cdot 13 \\
15 \cdot 4\end{array}$ & ** & $\begin{array}{l}\text { NS } \\
\text { NS }\end{array}$ & $\begin{array}{l}\text { NS } \\
\text { NS }\end{array}$ & $\begin{array}{l}\text { NS } \\
\text { NS }\end{array}$ & $\begin{array}{l}\text { NS } \\
\text { NS }\end{array}$ \\
\hline \multicolumn{13}{|c|}{ Molar proportions of individual SCFA (mmol/mol) } \\
\hline Acetate & 718 & 711 & 681 & 721 & 717 & 692 & $16 \cdot 4$ & NS & NS & NS & NS & NS \\
\hline Propionate & 191 & 191 & 208 & 183 & 157 & 171 & $9 \cdot 8$ & ** & NS & NS & NS & NS \\
\hline Isobutyrate & 4 & 3 & 7 & 1 & 4 & 5 & 1.4 & NS & $*$ & NS & NS & NS \\
\hline Butyrate & 70 & 70 & 73 & 84 & 101 & 122 & $10 \cdot 9$ & $*$ & $*$ & NS & $*$ & NS \\
\hline Isovalerate & 8 & 16 & 17 & 8 & 7 & 6 & $2 \cdot 2$ & $* * *$ & * & $*$ & NS & NS \\
\hline Valerate & 8 & 9 & 14 & 3 & 5 & 4 & 1.4 & $* * *$ & $*$ & NS & NS & NS \\
\hline
\end{tabular}

Lin, linear; Dev, deviations from linear effect.

${ }^{*} P<0.05 ;{ }^{* *} P<0.01 ;{ }^{* * *} P<0.001$.

$\uparrow$ See Table 1 for diet details and Fig. 1 for experimental design.

¥ See pp. 395-397 for further details of statistical methodology. 
Table 4. Adaptation experiment. Concentrations of short-chain fatty acids (umol/l) and of 3hydroxybutyrate $(3 \mathrm{OHB} ; \mu \mathrm{mol} / \mathrm{l})$ in whole blood from rats previously adapted to a whitebread-based diet ( $\mathrm{WHI} ; 0 \mathrm{~g}$ beans $/ \mathrm{kg}$ ) for $10 \mathrm{~d}$ and either continuing on this diet or changing to diet WH4 (450 g haricot beans (Phaseolus vulgaris) $/ \mathrm{kg}$ ) for a further $3 \mathrm{~d} \dagger$

(Mean values for five rats per treatment)

\begin{tabular}{|c|c|c|c|c|c|c|c|c|c|c|c|c|}
\hline \multirow{3}{*}{$\begin{array}{l}\text { Diet ... } \\
\text { Beans in diet }(\mathrm{g} / \mathrm{kg}) \ldots \\
\text { Sampling day... }\end{array}$} & \multirow{2}{*}{\multicolumn{3}{|c|}{$\begin{array}{c}\text { WH1 } \\
0\end{array}$}} & \multirow{2}{*}{\multicolumn{3}{|c|}{$\begin{array}{c}\text { WH4 } \\
450\end{array}$}} & \multirow[b]{3}{*}{ SEM } & \multicolumn{5}{|c|}{ Statistical significance of treatments } \\
\hline & & & & & & & & \multirow[b]{2}{*}{ Diet } & \multirow{2}{*}{$\begin{array}{l}\text { Time } \\
\text { (Lin) }\end{array}$} & \multirow{2}{*}{$\begin{array}{c}\text { Time } \\
\text { (Dev) }\end{array}$} & \multirow{2}{*}{$\begin{array}{c}\text { Diet } \times \\
\text { time } \\
\text { (Lin) }\end{array}$} & \multirow{2}{*}{$\begin{array}{l}\text { Diet } \times \\
\text { time } \\
\text { (Dev) }\end{array}$} \\
\hline & 1 & 2 & 3 & 1 & 2 & 3 & & & & & & \\
\hline \multicolumn{13}{|l|}{ Portal blood } \\
\hline Acetate & 983 & 739 & 585 & 1191 & 881 & 1125 & $124 \cdot 8$ & $* *$ & NS & NS & NS & NS \\
\hline Propionate & 94 & 77 & 47 & 172 & 163 & 180 & $16 \cdot 1$ & $* * *$ & NS & NS & NS & NS \\
\hline Butyrate & 28 & 26 & 20 & 157 & 94 & 112 & $36 \cdot 8$ & $* *$ & NS & NS & NS & NS \\
\hline $3 \mathrm{OHB}$ & 55 & 27 & 17 & 93 & 80 & 53 & $16 \cdot 4$ & $* *$ & $*$ & NS & NS & NS \\
\hline \multicolumn{13}{|l|}{ Heart blood } \\
\hline Acetate & 589 & 615 & 735 & 680 & 755 & 575 & $102 \cdot 2$ & NS & NS & NS & NS & NS \\
\hline Propionate & 40 & 24 & 21 & 46 & 26 & 32 & 6.4 & NS & $*$ & NS & NS & NS \\
\hline $3 \mathrm{OHB}$ & 28 & 27 & 26 & 87 & 58 & 85 & 14.9 & $* * *$ & NS & NS & NS & NS \\
\hline
\end{tabular}

Lin, linear; Dev, deviations from linear effect.

${ }^{*} P<0.05 ;{ }^{* *} P<0.01 ; * * * P<0.001$.

$\dagger$ See Table 1 for diet details and Fig. 1 for experimental design.

$\ddagger$ See pp. 395-397 for further details of statistical methodology.

Table 5. Balance experiment. Food DM intake, indigestibility, growth rate and aspects of nitrogen metabolism in rats given white-bread-based diets containing 0-450 $\mathrm{g}$ cooked haricot beans (Phaseolus vulgaris) $/ \mathrm{kg} \dagger$

(Mean values for five rats per diet)

\begin{tabular}{|c|c|c|c|c|c|c|c|c|}
\hline \multirow{2}{*}{$\begin{array}{l}\text { Diet ... } \\
\text { Beans in diet }(\mathrm{g} / \mathrm{kg}) \ldots\end{array}$} & \multirow{2}{*}{$\begin{array}{c}\text { WHI } \\
0\end{array}$} & \multirow{2}{*}{$\begin{array}{c}\text { WH2 } \\
150\end{array}$} & \multirow{2}{*}{$\begin{array}{c}\text { WH3 } \\
300\end{array}$} & \multirow{2}{*}{$\begin{array}{c}\text { WH4 } \\
450\end{array}$} & \multirow[b]{2}{*}{ SEM } & \multicolumn{3}{|c|}{$\begin{array}{l}\text { Statistical significance } \\
\text { of dietary effects }\end{array}$} \\
\hline & & & & & & Lin & Quad & Dev \\
\hline DM intake $(g / 7 d)$ & $101 \cdot 5$ & $100 \cdot 8$ & $99 \cdot 8$ & $99 \cdot 1$ & $0 \cdot 18$ & $* * *$ & NS & NS \\
\hline DM indigestibility $\$$ & 0.034 & 0.057 & 0.083 & $0 \cdot 110$ & 0.0013 & $* * *$ & NS & NS \\
\hline Weight gain $(g / 7 \mathrm{~d})$ & 38 & 43 & 39 & 29 & $2 \cdot 7$ & $*$ & $*$ & NS \\
\hline $\mathrm{N}$ intake $(\mathrm{g} / 7 \mathrm{~d})$ & $2 \cdot 46$ & $2 \cdot 49$ & $2 \cdot 58$ & $2 \cdot 64$ & 0.005 & $* * *$ & $*$ & $*$ \\
\hline Faecal $N$ output $(g / 7 d)$ & $0 \cdot 16$ & $0 \cdot 36$ & 0.54 & $0 \cdot 75$ & 0.008 & $* * *$ & NS & NS \\
\hline Urinary $N$ output $(g / 7 d)$ & $1 \cdot 37$ & $1 \cdot 23$ & $1 \cdot 21$ & $1 \cdot 31$ & 0.054 & NS & $*$ & NS \\
\hline
\end{tabular}

Lin, Quad, Dev; linear, quadratic and deviations from linear and quadratic effects of dietary bean concentration.

$* P<0.05 ; * * * P<0.001$.

+ For details of diets and procedures, see Table 1 and pp. 394-397.

+ Faecal DM output (g)/g DM consumed.

OM fermented in the LB (Mathers, 1991). Since final body weight for rats fed on diet WH4 was only $5 \%$ less than those fed on diet $\mathrm{WH} 1$, it seems unlikely that this factor will have had a major influence on digestive function.

Ileal flows of DM and OM increased strongly linearly $(P<0.001)$ with each increment of beans in the diet (Table 6). There was a corresponding but smaller increase in faecal OM 
Table 6. Balance experiment. Flows of $D M$ and organic matter $(O M)$ from the terminal ileum, $O M$ disappearance in the large bowel $(L B)$ and apparent digestibility of $D M$ measured at the terminal ileum, caecum and faeces of rats given white-bread-based diets containing $0-450 \mathrm{~g}$ cooked haricot beans (Phaseolus vulgaris) $/ \mathrm{kg} \dagger$

(Mean values for five rats per diet)

\begin{tabular}{|c|c|c|c|c|c|c|c|c|}
\hline \multirow[b]{2}{*}{$\begin{array}{l}\text { Diet... } \\
\text { Beans in diet }(\mathrm{g} / \mathrm{kg}) \ldots\end{array}$} & \multirow[b]{2}{*}{$\begin{array}{c}\text { WH1 } \\
0\end{array}$} & \multirow[b]{2}{*}{$\begin{array}{c}\text { WH2 } \\
150\end{array}$} & \multirow[b]{2}{*}{$\begin{array}{l}\text { WH3 } \\
300\end{array}$} & \multirow[b]{2}{*}{$\begin{array}{l}\text { WH4 } \\
450\end{array}$} & \multirow[b]{2}{*}{ SEM } & \multicolumn{3}{|c|}{$\begin{array}{l}\text { Statistical significance } \\
\text { of dietary effects }\end{array}$} \\
\hline & & & & & & Lin & Quad & Dev \\
\hline \multicolumn{9}{|l|}{ Ileal flow $(\mathrm{g} / \mathrm{d})$} \\
\hline DM & 1.84 & 3.01 & $3 \cdot 24$ & $4 \cdot 42$ & $0 \cdot 216$ & *** & NS & NS \\
\hline $\mathrm{OM}$ & 0.72 & $1 \cdot 54$ & 1.87 & $3 \cdot 04$ & 0.125 & $* * *$ & NS & $*$ \\
\hline Faecal OM output (g/d) & 0.32 & 0.63 & 0.99 & $1 \cdot 30$ & 0.016 & $* * *$ & NS & NS \\
\hline OM disappearance in $\mathrm{LB}(\mathrm{g} / \mathrm{d})$ & 0.40 & 0.91 & 0.88 & 1.73 & $0 \cdot 121$ & **** & NS & $*$ \\
\hline $\begin{array}{l}\text { Proportion of ileal OM } \\
\text { flow disappearing in LB }\end{array}$ & 0.44 & 0.42 & 0.53 & 0.44 & 0.025 & NS & NS & $* *$ \\
\hline \multicolumn{9}{|l|}{ DM digestibility $\neq$} \\
\hline Ileum & 0.87 & 0.79 & 0.77 & 0.69 & 0.019 & **** & NS & NS \\
\hline Caecum & 0.96 & 0.93 & 0.91 & 0.85 & 0.004 & *** & $* *$ & NS \\
\hline Faeces & 0.96 & 0.95 & 0.92 & 0.85 & 0.011 & **** & * & NS \\
\hline
\end{tabular}

Lin, Quad, Dev; linear, quadratic and deviations from linear and quadratic effects of dietary bean concentration.

$* P<0.05 ; * * P<0.01 ; * * * P<0.001$.

$\dagger$ For details of diets and procedures, see Table 1 and pp. 394-397.

$\ddagger$ Estimated by the marker ratio method.

output so that the quantity of OM disappearing between the terminal ileum and faeces was $1.73 \mathrm{~g} / \mathrm{d}$ with the highest bean diet (WH4) compared with only $0.40 \mathrm{~g} / \mathrm{d}$ for the basal diet (WH1). The apparent fermentability of OM across the LB of ileal-delivered OM was similar for all diets (0.46 (SE 0.013)). Apparent digestibility of DM when measured at the terminal ileum, caecum and faeces declined linearly with increasing bean intake. The fall was more marked for ileal samples than for caecal or faecal samples with the latter two sites of measurement resulting in very similar values.

Caecal pH fell by 0.3 units between diets WH1 and WH4 (Table 7) but changes in total SCFA concentration were inconsistent across diets and associated with relatively large between-animals within-diets variation (CV 0.22). The major effect of increasing bean intake on molar proportions of individual caecal SCFA was the increase in butyrate (from 68 to $184 \mathrm{mmol} / \mathrm{mol}$ ) at the expense of all the other acids but especially acetate.

Concentrations of all three SCFA in portal blood increased as bean intake increased but the linear effect was statistically significant for propionate and butyrate only (Table 8). Propionate concentration increased nearly twofold whilst butyrate concentration was more than five times greater in animals fed on diet WH4 compared with WH1. Acetate was the major SCFA detected in heart blood with concentrations approximately 15 times greater than for propionate. There was considerable between-animals variation and there were no statistically significant effects of diet. $30 \mathrm{HB}$ concentration in both portal and heart blood increased linearly with increasing intake of beans, with higher concentrations in heart than in portal blood.

Using a MLR approach, separate estimates of digestibility for NSP in white bread and beans were obtained. In addition, MLR model 1 tested for possible effects of the presence of beans in the diet on the digestibility of bread NSP. The latter was found to be statistically 
Table 7. Balance study. Caecal $p H$ and short-chain fatty acids (SCFA) in rats given white-bread-based diets containing $0-450 \mathrm{~g}$ cooked haricot beans (Phaseolus vulgaris) $/ \mathrm{kg} \dagger$ (Mean values for five rats per diet)

\begin{tabular}{|c|c|c|c|c|c|c|c|c|}
\hline \multirow{2}{*}{$\begin{array}{l}\text { Diet ... } \\
\text { Beans in diet }(\mathrm{g} / \mathrm{kg}) \ldots\end{array}$} & \multirow{2}{*}{$\begin{array}{c}\text { WH1 } \\
0\end{array}$} & \multirow{2}{*}{$\begin{array}{c}\text { WH2 } \\
150\end{array}$} & \multirow{2}{*}{$\begin{array}{c}\text { WH3 } \\
300\end{array}$} & \multirow{2}{*}{$\begin{array}{c}\text { WH4 } \\
450\end{array}$} & \multirow[b]{2}{*}{ SEM } & \multicolumn{3}{|c|}{$\begin{array}{c}\text { Statistical significance } \\
\text { of dietary effects }\end{array}$} \\
\hline & & & & & & Lin & Quad & Dev \\
\hline Caecal pH & $6 \cdot 2$ & 6.2 & 6.0 & 5.9 & 0.08 & $* *$ & NS & NS \\
\hline $\begin{array}{l}\text { Total SCFA (mmol/kg } \\
\text { caecal contents) }\end{array}$ & 141 & 133 & 110 & 125 & $12 \cdot 6$ & NS & NS & NS \\
\hline \multicolumn{9}{|c|}{ Molar proportions of individual SCFA $(\mathrm{mmol} / \mathrm{mol})$} \\
\hline Acetate & 724 & 684 & 710 & 643 & $28 \cdot 9$ & NS & NS & NS \\
\hline Propionate & 185 & 192 & 160 & 150 & $18 \cdot 0$ & NS & NS & NS \\
\hline Isobutyrate & 8 & 2 & 2 & 3 & 0.7 & $* * *$ & $* * *$ & NS \\
\hline Butyrate & 68 & $10 \overline{8}$ & 117 & 184 & $19 \cdot 0$ & $* * *$ & NS & NS \\
\hline Isovalerate & 7 & 5 & 6 & 5 & $1 \cdot 4$ & NS & NS & NS \\
\hline Valerate & 8 & 8 & 5 & 4 & $1 \cdot 7$ & NS & NS & NS \\
\hline
\end{tabular}

Lin, Quad, Dev; linear, quadratic and deviations from linear and quadratic effects of dietary bean concentration.

${ }^{*} P<0.05 ; * * P<0.01 ; * * * P<0.001$.

$\uparrow$ For details of diets and procedures, see Table 1 and pp. 394-397.

Table 8. Balance experiment. Concentrations of short-chain fatty acids ( $\mu$ mol/l) and of 3hydroxybutyrate $(3 \mathrm{OHB} ; \mu \mathrm{mol} / \mathrm{l})$ in whole blood from rats given white-bread-based diets containing $0-450 \mathrm{~g}$ cooked haricot beans (Phaseolus vulgaris) $/ \mathrm{kg} \dagger$

(Mean values for five rats per diet)

\begin{tabular}{|c|c|c|c|c|c|c|c|c|}
\hline \multirow{2}{*}{$\begin{array}{l}\text { Diet ... } \\
\text { Beans in diet }(\mathrm{g} / \mathrm{kg}) \ldots\end{array}$} & \multirow{2}{*}{$\begin{array}{c}\text { WH1 } 1 \\
0\end{array}$} & \multirow{2}{*}{$\begin{array}{c}\text { WH2 } \\
150\end{array}$} & \multirow{2}{*}{$\begin{array}{c}\text { WH3 } \\
300\end{array}$} & \multirow{2}{*}{$\begin{array}{c}\text { WH4 } \\
450\end{array}$} & \multirow[b]{2}{*}{ SEM } & \multicolumn{3}{|c|}{$\begin{array}{c}\text { Statistical significance } \\
\text { of dietary effects }\end{array}$} \\
\hline & & & & & & Lin & Quad & Dev \\
\hline \multicolumn{9}{|l|}{ Portal blood } \\
\hline Acetate & 733 & 1045 & 1027 & 1111 & $181 \cdot 4$ & NS & NS & NS \\
\hline Propionate & 78 & 89 & 117 & 137 & $15 \cdot 8$ & $* *$ & NS & NS \\
\hline Butyrate & 24 & 46 & 67 & 129 & $12 \cdot 1$ & $* * *$ & NS & NS \\
\hline 3ОНB & 15 & 32 & 19 & 64 & $8 \cdot 0$ & $* *$ & NS & $*$ \\
\hline \multicolumn{9}{|l|}{ Heart blood } \\
\hline Acetate & 548 & 635 & 745 & 591 & $87 \cdot 7$ & NS & NS & NS \\
\hline Propionate & 29 & 49 & 60 & 36 & $12 \cdot 1$ & NS & NS & NS \\
\hline $30 \mathrm{HB}$ & 22 & 42 & 30 & 88 & $13 \cdot 9$ & $* *$ & NS & NS \\
\hline
\end{tabular}

Lin, Quad, Dev; linear, quadratic and deviations from linear and quadratic effects of dietary bean concentration.

$* P<0.05 ; * * P<0.01 ; * * * P<0.001$.

$\dagger$ For details of diets and procedures, see Table 1 and pp. 394-397.

non-significant for total NSP and for each NSP component (Table 9) so that the simpler MLR model 2 (see pp. 396-397) provided an adequate description of the relationship between dietary intake and faecal output for these carbohydrates $\left(R^{2} 0.90-0.98\right)$. Apparent digestibility of total NSP was identical $(0.82)$ for both white bread and haricot beans. Noncellulosic polysaccharides (NCP) digestibility was much higher than that of cellulose for both foods. Digestibilities of the individual sugars making up the NSP fraction differed for 
Table 9. Balance experiment. Apparent digestibilities, estimated by multiple linear regression $(M L R)^{*}$, for non-starch polysaccharides $(N S P)$ of white bread and cooked haricot beans (Phaseolus vulgaris) when fed in mixed diets to rats

(Estimates were derived using individual values for twenty rats: mean values with their standard errors)

\begin{tabular}{|c|c|c|c|c|c|c|c|}
\hline & \multicolumn{2}{|c|}{ White bread } & \multicolumn{2}{|c|}{ Beans } & \multicolumn{2}{|c|}{$\alpha_{3} \dagger$} & \multirow[b]{2}{*}{$R^{2}$} \\
\hline & Mean & SE & Mean & $\mathbf{S E}$ & Mean & SE & \\
\hline \multicolumn{8}{|l|}{ MLR model 1} \\
\hline NSP & 0.85 & $0 \cdot 067$ & 0.83 & 0.022 & 0.07 & 0.117 & 0.97 \\
\hline NCP & 0.87 & $0 \cdot 040$ & 0.91 & 0.014 & 0.04 & 0.071 & 0.97 \\
\hline Cellulose & 0.60 & $0 \cdot 356$ & $0-25$ & 0.088 & 0.74 & $0-597$ & 0.97 \\
\hline Arabinose & 0.91 & 0.026 & 0.98 & 0.009 & 0.02 & 0.046 & 0.90 \\
\hline Xylose & 0.91 & $0 \cdot 036$ & 0.72 & 0.056 & 0.00 & $0 \cdot 067$ & 0.94 \\
\hline Mannose & 0.82 & $0-055$ & 0.76 & 0.061 & 0.02 & 0.085 & 0.91 \\
\hline Galactose & $0 \cdot 30$ & 0.094 & 0.80 & 0.027 & -0.07 & $0 \cdot 175$ & 0.98 \\
\hline Glucose & 0.83 & 0.103 & 0.68 & 0.037 & $0 \cdot 22$ & $0 \cdot 169$ & 0.97 \\
\hline Uronic acids & $0 \cdot 78$ & $0 \cdot 310$ & 0.90 & 0.015 & 0.42 & 0.558 & 0.96 \\
\hline \multicolumn{8}{|l|}{ MLR model 2} \\
\hline NSP & 0.82 & 0.054 & 0.82 & 0.014 & & & 0.97 \\
\hline NCP & 0.86 & 0.032 & 0.90 & 0.009 & & & 0.97 \\
\hline Cellulose & 0.34 & $0 \cdot 290$ & $0 \cdot 17$ & 0.062 & & & 0.97 \\
\hline Arabinose & 0.90 & 0.021 & 0.98 & 0.006 & & & 0.90 \\
\hline Xylose & 0.91 & 0.030 & 0.72 & 0.034 & & & 0.94 \\
\hline Mannose & 0.81 & 0.041 & 0.75 & 0.044 & & & 0.92 \\
\hline Galactose & 0.32 & 0.077 & 0.81 & 0.016 & & & 0.98 \\
\hline Glucose & 0.75 & 0.083 & 0.65 & 0.026 & & & 0.97 \\
\hline Uronic acids & 0.65 & 0.255 & 0.89 & 0.010 & & & 0.96 \\
\hline
\end{tabular}

NCP, non-cellulosic polysaccharides.

* For details of MLR models 1 and 2, see pp. 396-397.

$\dagger$ Additional effect of presence of beans on indigestibility of NSP fractions in white bread.

the two foods, with digestibility declining in the order xylose $>$ arabinose $>$ mannose $>$ glucose $>$ uronic acids $>$ galactose for white bread and in the order arabinose $>$ uronic acids $>$ galactose $>$ mannose $>$ xylose $>$ glucose for haricot beans.

\section{DISCUSSION}

\section{Adaptation of large bowel fermentation}

This study examined short- (1-3 d) and medium- (14 d) term adaptations of LB fermentation to alterations in substrate supply brought about by including cooked haricot beans in the diet of rats. When changed from the no-beans diet (WH1) to the highest bean diet (WH4), ileal output of OM, the major source of LB substrate, increased nearly fourfold within $1 \mathrm{~d}$ and was little different $14 \mathrm{~d}$ later. It is assumed that the additional $O M$ was provided principally by bean carbohydrates including NSP, RS and oligosaccharides (OS) of the raffinose family. Acute studies in healthy human ileostomists have shown that ingested NSP is essentially unchanged during passage through the stomach and small intestine (Englyst \& Cummings 1985, 1986, 1987). We are not aware of longer term studies which have examined NSP hydrolysis in the upper intestine of man or rats but the possibility of significant digestion at this site seems remote. Similarly it is assumed that the OS flow unchanged to the LB. Prediction of the amount of starch escaping digestion in the small intestine from measurements made on foods is less well established but it is now clear that a significant proportion of the starch in common human foods including breads and cooked and cooled beans is not digested before the LB (Englyst \& Kingman, 1990). 
Possible adaptation over time in digestion of RS has been little studied but evidence presented by Faulks et al. (1989) suggests no change in the extent of whole-gut RS digestion between $8 / 9$ and $17 / 18 \mathrm{~d}$ of feeding isolated $\alpha$-amylase-resistant pea and maize starches. More recent detailed studies of sites of digestion of these same in vitro $\alpha$-amylase-resistant starches in the rat suggest that feeding ' $\mathrm{RS}$ ' sources for $14 \mathrm{~d}$ (adaptation) resulted in greater disappearance of starch within the small intestine than in unadapted animals (Faulks et al. 1992). The possibility that adaptation of the small-intestinal capacity to digest certain starch fractions may occur requires further investigation. Our results are consistent with the conclusion that throughout the $14 \mathrm{~d}$ of the study the substrates flowing to the LB remained fairly similar for each diet.

If it is assumed that the amount and composition of substrate entering the LB stabilized quickly (perhaps within $1 \mathrm{~d}$ ) after dietary change, then subsequent alterations in fermentation pattern are brought about by alterations in the metabolic activity of the LB microflora as they adapt to the new environment. This new environment includes not only the additional amount and types of substrate but also the reduced $\mathrm{pH}$ and transit time, all of which will influence the functions of individual bacterial species and interactions between species. In the present study, introduction of the high-bean diet (WH4) caused an immediate fall in caecal $\mathrm{pH}$ to a value identical with that after $14 \mathrm{~d}$, but caused more gradual changes in pattern of caecal SCFA. In particular, the rise in butyrate proportion after $3 \mathrm{~d}$ was only about half that achieved after $14 \mathrm{~d}$ feeding the new diet. It may be calculated from the data of Goodlad \& Mathers (1990) that the turnover time for the caecal SCFA pool, i.e. the time taken at steady state for production of an amount of SCFA equivalent to that in the caecum, is only 1.5-3 h so this slow change in SCFA pattern is not due to dilution effects but to the time required for the microbial metabolism to approach a new equilibrium. Increases in caecal butyrate molar proportion often follow increased intakes of complex carbohydrates (Cheng et al. 1987; Tulung et al. 1987; Goodlad \& Mathers, 1990; Mathers et al. 1990) but Mathers \& Dawson (1991) have suggested that this is not simply a response to the additional substrate but may be strongly influenced by transit time. Tulung et al. (1987) reported differential changes in the relative concentrations of SCFA over a 3-week period after introduction of guar gum or gum arabic whilst Walter et al. $(1986,1988)$ examined changes in response to wheat bran and gum arabic at 4,8 and 12 weeks. It is possible that these longer term changes in fermentation pattern are partially confounded with changes due to age/maturity of the test animal since we have found that age can have a significant effect on rat caecal SCFA pattern (Mathers et al. 1993). The lack of effect of dietary bean concentration on total SCFA concentration in the balance study (Table 7) despite the changes observed in the adaptation experiment (Table 3) might be due to differences in animal maturity but remain without satisfactory explanation.

The digestibility of white-bread and bean NSP fractions and their constituent components observed in the present study are similar to those reported for different batches of the same foods by Key \& Mathers $(1993 a, b)$. The observation that the apparent fermentability of OM entering the LB was unaffected by diet (Table 6) is in good agreement with the finding that NSP digestibility was similar for both white bread and beans and that there was no detectable RS in faeces on any diet. Therefore, in the present study the rat LB remained equally effective in fermentation over an approximately fourfold range in substrate supply from conventional human foods, so confirming earlier studies (Goodlad \& Mathers, 1990, 1991).

\section{Towards a quantitative description of large-bowel fermentation}

Quantitative models of LB fermentation require detailed knowledge of the amount and chemical composition of substances supplied to the organ in ileal digesta and leaving as faeces. Such input-output relationships together with information on fermentation 
stoichiometry could be used to predict energy salvage by this gut compartment (Mathers, 1991, 1992). An attempt has been made using data from the present study (balance experiment) to provide a partial fractionation of ileal digesta and faecal OM and to describe, quantitatively, some consequences of fermentation. The model uses the following information:

$I=\mathrm{OM}$ flow from terminal ileum (measured directly),

$A=$ NSP flow from terminal ileum (estimated as NSP intake),

$B=\mathrm{RS}$ flow from terminal ileum (estimated as apparent RS intake: note that this may underestimate total RS intake (see p. 403)),

$F=$ faecal OM output (measured directly),

$D=$ NSP output in faeces (measured directly),

and estimates of the following variables are obtained by calculation:

$C=\mathrm{OM}$ other than NSP and apparent RS flowing from the terminal ileum,

$E_{1}=$ bacterial OM attributable to NSP and RS fermentation (in the present study, all RS appeared to be fermented in the LB),

$E_{2}=$ bacterial OM attributable to fermentation of other OM,

$G=\mathrm{OM}$ other than NSP and bacterial OM appearing in faeces.

Estimates of $E_{1}$ and $E_{2}$ are obtained assuming that fermentation of $1 \mathrm{~g}$ OM yields $0.263 \mathrm{~g}$ bacterial OM (see Cummings, 1984 and Mathers, 1991 for basis). The four unknown quantities $C, E_{1}, E_{2}$, and $G$ can then be calculated from the following relationships:

$$
\begin{aligned}
& C=I-(A+B), \\
& E_{1}=(A+B-D) \times 0.263,
\end{aligned}
$$

since

$$
\begin{aligned}
& E_{2}+G=F-\left(D+E_{1}\right), \\
& \text { and } \\
& E_{2}=\left(C-\left(F-\left(D+E_{1}\right)\right)\right) \times 0.357 .
\end{aligned}
$$

Note: $1 \mathrm{~g}$ truly fermented OM yields $0.263 \mathrm{~g}$ bacterial $\mathrm{OM}$, so $1 \mathrm{~g}$ apparently fermented $\mathrm{OM}$ yields $0.263 /(1-0.263)=0.357 \mathrm{~g}$ bacterial OM.

Then

$$
G=F-\left(D+E_{1}\right)-E_{2} \text {. }
$$

The results obtained are summarized in Fig. 2. Although increasing the proportion of beans in the diet increased the proportion of ileal OM accounted for by NSP and RS, other unidentified substances $(C)$ provided a major part $(0.30-0.58)$ of the potential substrate for the LB for all diets. The latter probably included undigested food fragments such as other forms of RS (Englyst et al. 1992), OS (from the haricot beans) and undigested dietary protein, together with endogenous materials (Cummings \& Englyst, 1987). Of faecal OM, undigested NSP were a minor component $(0 \cdot 13-0 \cdot 22)$ for all diets whilst bacterial cells were estimated to contribute a mean of 0.44 , leaving, on average, 0.37 in unidentified forms. It is unlikely that the latter contains OS since an earlier study found no OS in rat faeces after consumption of relatively large amounts provided in raw peas (Goodlad \& Mathers, 1990). Validity of the fractionation attempted above is dependent on the assumed value for the net yield of bacterial cells per unit OM truly fermented. The value used here was derived from in vivo studies in man (Cummings, 1984) and whilst it is similar to estimates from investigations of rumen fermentation (Mathers \& Miller, 1981; Agricultural Research Council, 1984) it should not be assumed that the value applies universally. A further unknown factor is the extent of addition of endogenous materials to the LB from the mucosal surface (as distinct from inflow from the terminal ileum). Mucus and sloughed epithelial cells are the most likely sources of this $O M$ and require quantification. The possibility that greater production of butyrate may stimulate mucin synthesis (Finnie $e t$ al. 1995) adds a further complication to these calculations. 
(a)

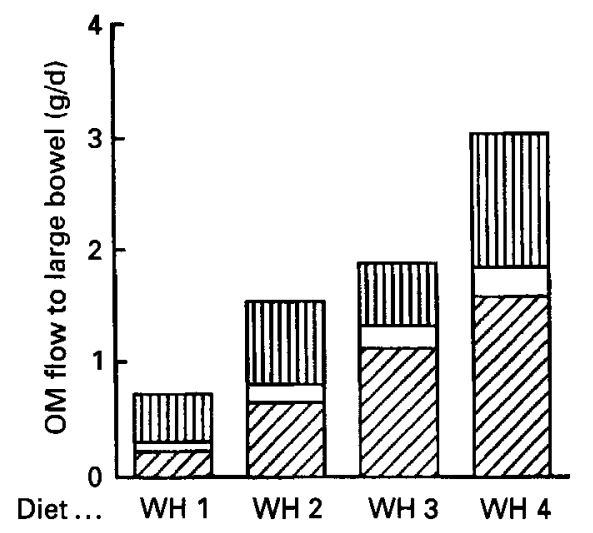

(b)

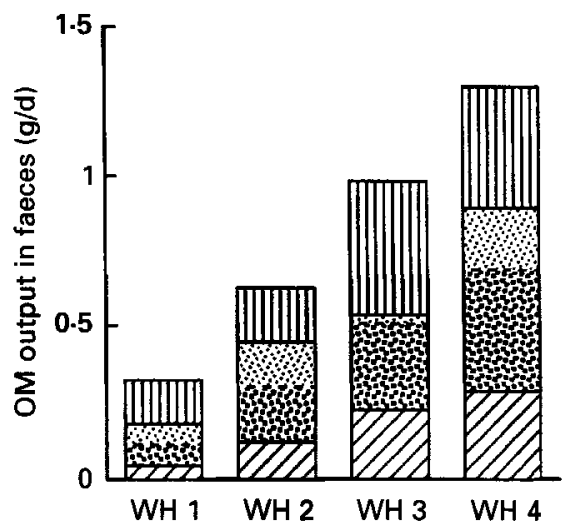

Fig. 2. Partial fractionation of organic matter (OM) flow to the large bowel (a) in ileal digesta and (b) leaving the organ as faeces; see p. 395 for details of how estimates were made. (四), Non-starch polysaccharides (NSP); ( $\square$ ), resistant starch (RS); (四), 'other' undefined OM; (영 ) bacterial OM attributable to fermentation of NSP and RS; (图) bacterial OM from fermentation of 'other' OM.

\section{CONCLUSIONS}

The rat small intestine appears to be capable of rapid adaptation to abrupt changes in diet composition so that within $1 \mathrm{~d}$ of diet change the flow of undigested material from the terminal ileum is established at a new level which persists for at least 2 weeks. Increasing intakes of NSP and RS which increase substrate supply to the LB provoke a rapid and sustained decrease in caecal $\mathrm{pH}$ but the pattern of bacterial end-products (SCFA) changes more gradually and is not complete by $3 \mathrm{~d}$. This may be a consequence of changing dominance in bacterial species (Mathers et al. 1990) but more subtle changes in metabolic activity may be involved.

Human food consumption in Western countries is frequently characterized by substantial changes in the amount and type of indigestible carbohydrates from meal to meal and day to day. It is probable that this results in marked variations in substrate supply to the colonic flora. Whilst the latter have considerable 'spare' capacity to ferment extra substrate, this will probably result in changes in SCFA patterns and may create short-term instabilities in metabolic activity. The consequences, if any, of such perturbations are unknown.

F.B.K. was in receipt of an Agricultural and Food Research Council Food Research Studentship whilst this study was carried out.

\section{REFERENCES}

Agricultural Research Council (1984). The Nutrient Requirements of Ruminant Livestock, Supplement no. 1. Slough: Commonwealth Agricultural Bureaux.

Cheng, B.-Q., Trimble, R. P., Illman, R. J, Stone, B. A. \& Topping, D. L. (1987). Comparative effect of dietary wheat bran and its morphological components (aleurone and pericarp-seed coat) on volatile fatty acid concentrations in the rat. British Journal of Nutrition 57, 69-76.

Cummings, J. H. (1984). Microbial digestion of complex carbohydrates in man. Proceedings of the Nutrition Society 43, 35-44.

Cummings, J. H. \& Englyst, H. N. (1987). Fermentation in the human large intestine and the available substrates. American Journal of Clinical Nutrition 45, 1243-1255.

Englyst, H. N. \& Cummings, J. H. (1984). Simplified method for the measurement of total non-starch polysaccharides by gas-liquid chromatography of constituent sugars as the alditol acetates. Analyst 109, 937-942.

Englyst, H. N. \& Cummings, J. H. (1985). Digestion of the polysaccharides of some cereal foods in the human small intestine. American Journal of Clinical Nutrition 42, 778-787. 
Englyst, H. N. \& Cummings, J. H. (1986). Digestion of the carbohydrates of banana (Musa paradisiaca sapientum) in the human small intestine. American Journal of Clinical Nutrition 44, 42-50.

Englyst, H. N. \& Cummings, J. H. (1987). Digestion of polysaccharides of potato in the small intestine of man. American Journal of Clinical Nutrition 45, 423-431.

Englyst, H. N. \& Kingman, S. M. (1990). Dietary fiber and resistant starch. A nutritional classification of plant polysaccharides. In Dietary Fiber, pp. 49-65 [D. Kritchevsky, C. Bonfield and J. W. Anderson, editors] New York: Plenum Publishing Corporation.

Englyst, H. N., Kingman, S. M. \& Cummings, J. H. (1992). Classification and measurement of nutritionally important starch fractions. European Journal of Clinical Nutrition 46, Suppl. 2, S33-S50.

Faulks, R. M., Roe, M. A. \& Livesey, G. (1992). Sites of digestion and absorption of $\alpha$-amylase-resistant starches in the rat. European Journal of Clinical Nutrition 46, Suppl. 2, S123-S124.

Faulks, E. M., Southon, S. \& Livesey, G. (1989). Utilization of $\alpha$-amylase (EC 3.2.1 .1.)-resistant maize and pea (Pistum sativum) starch in the rat. British Journal of Nutrition 61, 291-300.

Finnie, I. A., Dwarakanath, A. D., Taylor, B. A. \& Rhodes, J. M. (1995). Colonic mucin synthesis is increased by sodium butyrate. Gut 36, 93-99.

Goodlad, J. S. \& Mathers, J. C. (1990). Large bowel fermentation in rats given diets containing raw peas (Pisum sativum). British Journal of Nutrition 64, 569-587.

Goodlad, J. S. \& Mathers, J. C. (1991). Digestion by pigs of non-starch polysaccharides in wheat and raw peas (Pisum sativum) fed in mixed diets. British Journal of Nutrition 65, 259-270.

Key, F. B. \& Mathers, J. C. (1993a). Gastrointestinal responses of rats fed on white and wholemeal breads: complex carbohydrate digestibility and the influence of dietary fat content. British Journal of Nutrition 69, 481-495.

Key, F. B. \& Mathers, J. C. (1993b). Complex carbohydrate digestion and large bowel fermentation in rats given wholemeal bread and cooked haricot beans (Phaseolus vulgaris) fed in mixed diets. British Journal of Nutrition 69, 497-509.

Lloyd, B., Burrin, J., Smythe, P. \& Alberti, K. G. M. M. (1978). Enzymic fluorometric continuous flow assays for blood glucose, lactate, pyruvate, alanine, glycerol and 3-hydroxybutyrate. Clinical Chemistry 34, $1724-1729$.

Mallett, A. K., Bearne, C. A., Young, P. J., Rowland, I. R. \& Berry, C. (1988). Influence of starches of low digestibility on the rat caecal microflora. British Joumal of Nutrition 60, 597-604.

Mathers, J. C. (1991). Digestion of non-starch polysaccharides by non-ruminant omnivores. Proceedings of the Nutrition Society 50, 161-172.

Mathers, J. C. (1992). Energy value of resistant starch. European Journal of Clinical Nutrition 46, Suppl. 2, S129-S130.

Mathers, J. C. \& Dawson, L. D. (1991). Large bowel fermentation in rats eating processed potatoes. British Journal of Nutrition 66, 313-329.

Mathers, J. C., Fernandez, F., Hill, M. J., McCarthy, P. T., Shearer, M. J. \& Oxley, A. (1990). Dietary modification of potential vitamin $\mathrm{K}$ supply from enteric bacterial menaquinones in rats. British Journal of Nutrition 63, 639-652.

Mathers, J. C., Kennard, J. \& James, O. F. W. (1993). Gastrointestinal responses to oats consumption in young adult and elderly rats: digestion, large bowel fermentation and crypt cell proliferation rates. British Journal of Nutrition 70, 567-584.

Mathers, J. C. \& Miller, E. C. (1981). Quantitative studies of food protein degradation and the energetic efficiency of microbial protein synthesis in the rumen of sheep given chopped lucerne and rolled barley. British Journal of Nutrition 45, 587-604.

Nyman, M., Asp, N.-G., Cummings, J. \& Wiggins, H. (1986). Fermentation of dietary fibre in the intestinal tract: comparison between man and rat. British Journal of Nutrition 55, 487-496.

Paul, A. A. \& Southgate, D. A. T. (1978). McCance and Widdowson's The Composition of Foods, 4th ed. London: H. M. Stationery Office.

Roediger, W. E. W. (1982). Utilization of nutrients by isolated epithelial cells of the rat. Gastroenterology 83 , 424-429.

Sakata, T. (1987). Stimulatory effect of short-chain fatty acids on epithelial cell proliferation in the rat intestine: a possible explanation for trophic effects of fermentable fibre, gut microbes and luminal trophic factors. British Journal of Nutrition 58, 95-103.

Scheppach, W., Fabian, C., Sachs, M. \& Kasper, H. (1988). The effect of starch malabsorption on fecal shortchain fatty acid excretion in man. Scandinavian Journal of Gastroenterology 23, 755-759.

Tulung, B., Rémésy, C, \& Demigné, C. (1987). Specific effects of guar gum or gum arabic on adaptation of caecal digestion to high fibre diets in the rat. Journal of Nutrition 117, 1556-1561.

Venter, C. S. \& Vorster, H. H. (1989). Possible metabolic consequences of fermentation in the colon for humans. Medical Hypotheses 29, 161-166.

Walter, D. J., Eastwood, M. A., Bryden, W. G. \& Elton, R. A. (1986). An experimental design to study colonic fibre fermentation in the rat: the duration of feeding. British Journal of Nutrition 55, 465-479.

Walter, D. J., Eastwood, M. A., Brydon, W. G. \& Elton, R. A. (1988). Fermentation of wheat bran and gum arabic in rats fed on an elemental diet. British Journal of Nutrition 60, 225-232. 